\title{
CHUVASH SUBSTRATE OF CHEBOKSARY REGIONAL DIALECT OF RUSSIAN
}

\author{
Eduard V. Fomin ${ }^{1^{*}}$, Tamara N. Erina ${ }^{2}$ \\ ${ }^{1}$ Assoc. Prof., Chuvash State Institute of Culture and Arts, RUSSIA, yeresen@yandex.ru \\ ${ }^{2}$ Assoc. Prof., Chuvash State University, RUSSIA, tnerina@rambler.ru \\ ${ }^{*}$ Corresponding Author
}

\begin{abstract}
The article is devoted to the study of the peculiarities of the Russian colloquial speech of the inhabitants of Cheboksary, the capital city of the Chuvash Republic, Russia. It is believed that it was the Chuvash language that had a considerable influence on the formation of these peculiarities. The purpose of the paper is to highlight the role of the Chuvash substrate in the formation of the regional dialect of Russian in Cheboksary. The traditional linguistic methods are applied to analyze the language material composed of natural discourses of inhabitants of Cheboksary. The culture of speech is in the focus of the research done on the linguistic data provided by both the Russian and the Chuvash scholars. The authors come to the conclusion that the Russian language constantly exposed to the Chuvash linguistic and cultural environment has been experiencing significant local influence and herewith acquiring unique features. Substrate elements are realized at all levels of the language system. In the Cheboksary regional dialect, the Chuvash influence on the Russian language is expressed in an increase in the frequency of Russian language units, which most closely correspond to the Chuvash counterparts. Phonetic markers are the major elements that make the speech of the residents of Cheboksary sound specifically. Orthoepic peculiarities of Cheboksary residents in a number of cases are characterized by their pronouncing certain words literally and shifting stress in some frequently used words. The lexical specificity of the Russian colloquial speech of the inhabitants of Cheboksary is accounted for by a number of Chuvashisms, local urbanonyms and semantic calques of Chuvash words. Morphological markers are the result of the specific use of Russian language units due to the influence of the process of acculturation. The word-building markers of the Cheboksary regional dialect are associated with the use of derivational formants of Chuvash origin in Russian word formation and Russian suffixes in the composition of Chuvash words. The syntactic level markers are represented in sentence models and by their peculiar features. In the Cheboksary regional dialect instead of Russian SVO sentence model Chuvash SOV sentence model is preferred. It is worth mentioning also that participial constructions are characteristic of oral speech. The authors argue that the regional dialect of Russian in Cheboksary is a variant of the Russian literary language. Its objective existence and functioning is the result of its exposure to the influence of the Chuvash language and culture. The peculiarities of the regional dialect of Russian are revealed in codified language units that have experienced the interfering impact of the Chuvash language.
\end{abstract}

Keywords: Russian language, Chuvash language, substrate, language contacts, regional norm, Cheboksary regional dialect of Russian language.

\section{INTRODUCTION}

The work under consideration is devoted to the issue of Russian and Chuvash language contacts in the light of a modern approach to contactological studies. Until now, contactological research has focused mainly on the study of Russian influence on the Chuvash language. However, studies of recent years have indicated that a subtle, more often a hardly noticeable impact of the Chuvash language on Russian regional speech is quite an interesting phenomenon. 
The authors of the work are of the opinion that the regional variants of the Russian language can be recognized as a kind of metalect, and not just a non-literary entity as they have been qualified in Russian linguistics till now. At least the study of the Cheboksary regional dialect of Russian allows us to make a statement that such a conclusion is correct.

\section{METHODOLOGY}

The aim of the study is to establish the significance of the Chuvash substrate in the formation of the colloquial Cheboksary regional dialect of the Russian language.

The study is based on the authors' long-term observations of the discourses of residents of the city of Cheboksary, the speech samples analyses recorded in community environment in natural conditions.

An integrative approach to the language material from the standpoint of speech culture, sociolinguistics and onomastics is used in the work.

The aspect of speech culture is of paramount importance in the study. From the point of view of the literary language standards, specific and unique features existing in regional language variants are often stated as deviations from the norm. The local material needs an orthological characterization of the observed discrepancies between literary and regional norms and an explanation of why and how they developed.

The sociolinguistic aspect of the study focusing on clarification of the extralinguistic conditions for the coexistence of the Russian and Chuvash languages is just in the mainstream of the research as it allows to establish an initial onset on which concrete linguistic studies will be built in the future. Moreover, the orthological approach within the framework of our research is sociolinguistic one in its nature.

Using onomastic material in studying the regional specificity of the Russian language is mandatory. Regional features can primarily be traced in urbanonyms of local origin, as well as in the names of organizations, institutions, firms, shops, etc.

The functioning of the Russian literary language is currently being studied within the framework of a new approach that involves taking into account specific linguistic parameters used to highlight its regional variations. However, very often regionalisms, i. e. regional dialects are qualified from the standpoint of the literary norm as non-normative.

It can be assumed that qualifying regional dialects as linguistic entities functioning in the peripheral area of language in use is accounted by the choice of the object of research presented by colloquialisms. However, the peculiar use of certain linguistic units and their high frequency in speech, which occurs in compliance with literary norms, should anyway be considered in the context of the literary language. In this regard, the speech of Cheboksary residents can be considered as the ideal result of mastering the Russian literary language under the influence of the native Chuvash language.

The article contains Russian and Chuvash material in international transcription.

Only those markers that were formed with the participation of the Chuvash are analyzed in the article. For a complete list of markers, see: (Fomin, Erina, 2019).

\section{RESULTS}

\subsection{Cheboksary Regional Dialect of the Russian Language: General Data}

Cheboksary, the capital city of the Chuvash Republic, was founded in 1469. Its population is half a million people. With its urban agglomeration Cheboksary comprises the population of more than 700 thousand people that makes up about 60 per cent of the republic's total population. The ethnic composition of Cheboksary is made up of Chuvash -63 per cent, Russians - 34 per cent, representatives of other peoples - three percent. The main languages are Russian and Chuvash.

Cheboksary is distinguished by its specific character of Russian speech, which is commonly called the Cheboksary "regiolect", i. e. Cheboksary regional dialect of Russian.

The Cheboksary Regiolect is a complex formation, conditioned, on the one hand, by the development of the internal potencies of the Russian language, and on the other hand, by the impact of the Chuvash language.

At the turn of the $19^{\text {th }}-20^{\text {th }}$ centuries the first ever in history research devoted to studying Russian colloquial speech used by the Chuvash people was done V. A. Bogoroditsky who highlighted and described its peculiar features in his work "Russian speech inaccuracies of the Chuvash" (Bogoroditsky, 1900). 
Subsequently, for more than a century, the Russian speech of Cheboksary residents has never become an object of special linguistic analysis. The reason for this is the late formation of the Cheboksary regional dialect of Russian (1980-1990) and that of Russian linguistic regional studies (Livinskaya, 2015, p. 37-42).

It was not until 2010 that special linguistic works on the Russian language in Cheboksary appeared. Some years later a scientific conference "Culture and Arts: History and Modernity" designed to draw attention to the peculiar features of the speech of Cheboksary residents was initiated. The proceedings of the conference were published under the same title in 2013 (Culture, 2013). The idea was so unexpected and interesting that it caused a lively response in the linguistic environment. From that time on a new stage in the development of linguistic and scientific research into the Cheboksary regional dialect of Russian began.

Orthological and sociolinguistic approaches were identified in the study of the peculiarities of colloquial speech of Cheboksary residents at the very onset.

Many works written in the orthological aspect and aimed mainly at considering discrepancies between the general literary norm and regional variants are devoted on the whole to the description of the peculiarities of the speech of Cheboksary residents (Erina, Fomin, 2018, p. 81-84), (Erina, Fomin, 2019, p. 34-39). The linguistic analysis of the recorded data is done at the phonetic, lexical and grammatical levels in order to have a holistic idea of the region dialect of Russian (Myshkin, 2013, p. 150-153), (Erina, 2018, p. 40-41), (Fomin, 2018, p. 48-51), (Erina, 2019, p. 24-25), (Fomin, Erina, 2019, p. 59-61).

The sociolinguistic studies of the Cheboksary regional dialect is represented by the works of E. Alos-i-Font. His contribution to studying the problems of using the Chuvash language by the inhabitants of Cheboksary is worth mentioning, too (Alos-i-Font, 2012, p. 82-97), (Alos-i-Font, 2014, p. 4-11). At first sight it might seem that the Chuvash language is a majoritarian language as native Chuvash account for 68 percent of the population of the republic and 63 percent in Cheboksary. Anyhow actually this is not the case as the number of native people speaking Chuvash is less than one might expect assuming by the afore mentioned percentages. The scientist devoted his research to revealing the reasons for the present day situation concerning the Chuvash language and considering the ways of its preservation from extinction.

In this respect one more work of E. Alos-i-Font is noteworthy. It is dedicated to the "symbol" of the Cheboksary regional dialect - a passenger's verbal request to a driver to stop a minibus using the phrase Ostav'te na sleduyuschey ostanovke 'Let me get off at the next stop' (Alos-i-Font, 2018).

It can be assumed that in the conditions of the Chuvash-Russian interethnic interaction in the capital of the Chuvash Republic, Cheboksary, qualitative parameters of Russian speech are formed, which become a model for all residents of the republic. These parameters are distinguished from those of other regions.

According to the observations of linguists in the conditions of the Cheboksary regional dialect, certain units of the national literary language being used repeatedly become a marker of regional speech. Chuvash inclusions, at first glance, obliged to dominate in the formation of a regional dialect, actually are used much less frequently in Cheboksary than in other national regions, for example, in Tatarstan or in the Caucasian republics.

The special features of the speech behavior of Cheboksary residents are formed under the influence of historical, geographical, socio-demographic and contactological factors. The above factors are expressed in the following events, processes and phenomena, the most important of which are the entry of Chuvashia into the Moscow state in 1551; the settlement of Russians on the Chuvash lands; Christianization of the pagan Chuvash beginning from the middle of the $18^{\text {th }}$ century; formation of the Chuvash autonomy with the center in the city of Cheboksary in 1920; democratization of public relations since the late 1980s; linking toponymy to geographic coordinates; the predominance of the Chuvash population with a native Chuvash language in the republic and the capital; Chuvash-Russian mixed marriages, which determine the Russian national identity of children; population mobility, during which intra-republican migration processes are observed and the formation of the Cheboksary agglomeration occurs; urbanization of the Chuvash population; the difference in the structure of contacting languages: Russian is the language of the Indo-European family, Chuvash is that of the Altai family; a powerful linguistic shift in the Chuvash environment (Erina, Fomin, 2018, p. 49-52).

The specific features of the Cheboksary regional dialect of Russian can be understood as one of the components of national or regional self-awareness, and also become an interesting material for studying the Chuvash influence on the Russian language. 


\subsection{Phonetic Markers}

Phonetic means are the main elements that form the specificity of the speech of Cheboksary residents. The main list of such markers is quite extensive, cf.:

- Absence of positional reduction of vowels [a], [o], [e], expressed in the clear pronunciation of standard allophones, cf.: [ja]zïk 'language', [ja]ponskij 'Japan', č[a]sï 'clock' instead of the literary form [ji $]$ - $\left[j^{e}{ }^{e}\right] z i ̈ k$, $\left[i^{e}\right]$ ponskij, $\left.\check{c}^{i} i^{e}\right] s i ̈$, which is due to the peculiarities of the phonetic system of the Chuvash language, in which reduced vowels, unlike Russian ones are phonemes and do not undergo positional changes;

- Absence of transition of [i] in [i] after consonants in phonetic words, e. g. ob [i]skusstve 'about art', $s$ [i]gorem 'with Igor', iz [i]ndii 'from India', $v$ [i]talii, cf. with literary ob [i]skusstve, s [i]gorem, iz [i]ndii; v [i]talii. In this case, the speakers pause between the preposition and the significant word: $o b \|$ iskusstve, $s \|$ Igorem, iz || Indii, v || Italii and clearly pronounce each of them, while in the Russian literary language the preposition and the significant word following it form an independent phonetic word, i. e. they are pronounced without a pause;

- Shifted stress in a number of high-frequency words, cf.: in Cheboksary Čuvašíja, čuváši instead of the literary form Čuvášija and the preferred čuvaši;

- The atypical stress in the popular surname Aleksandrov. Aleksandróv dominates (in the speech of nobility) instead of the expected form Aleksádrov (of peasant origin). However, it is common knowledge that there were no nobles of Chuvash origin in Russia. Chuvash surnames were adopted only by the middle of the $20^{\text {th }}$ century, therefore the noble form of the Aleksandróv surname should be recognized as non-functional and, due to its totality, qualified as an accentological marker of the Cheboksary regional dialect;

- Ascending intonation, giving the impression of a continuation of what was said, with the effect of swallowing the endings and ignoring pauses. The speech is characterized by speed and fluency. The sound pitch is high enough, flying;

- Imitation of the Chuvash accent. This feature usually manifests itself for humorous effects among people who know each other well enough. It is often complemented by other linguistic features (Fomin, 2018), cf.: [já ustála ya | tomój pod'om \k:a] instead of literary [já ustála užé, pojd'óm domój];

- High speech volume in public places. The reasons for this may be different extralinguistic factors. Anyhow observations indicate that Cheboksary residents have a great desire to show in this way a high level of proficiency in the more prestigious Russian language.

\subsection{Lexical Markers}

The following groups of lexical units belong to lexical markers of the Cheboksary regional dialect:

- Keywords with high frequency like čuvaš 'Chuvash', Čeboksarï 'Cheboksary', čuvašskij 'referring to Chuvash', čeboksarskij 'referring to Cheboksary';

- Regional urbanonyms as ulica Elgera 'Elger street', prospekt l. Jakovleva 'I. Jakovlev Avenue', magazin "Šupaškar" 'Shupashkar Supermarket', restoran "Ehrem huśa" 'Ehrem Huhz'ia restaurant'; kinoteatr "Sespel" 'Sespel cinema', gostinitsa "Atăl” 'Atal hotel', ostanovka "Obikovo" 'Obikovo stop', reka Pahča 'Pahcha river', Lakrejevskij les 'Lakrejevskij Les park'.

- Chuvashisms, i. e. Chuvash borrowings in a) names of drinks, dishes and products of the Chuvash national cuisine: serte 'goutweed', huplu 'pie with meat and potatoes', turăh 'curdled milk', ujran 'a kind of fermented milk drink based on turăh', kĕr sări 'autumn beer', čăkăt 'homemade cheese', šărttan 'homemade sausage'; b) etiquette forms of greeting and gratitude: salam 'hello', tavtapuś 'thank you', tarhasšăn 'please'; c) common words of different parts of speech: jultaš 'friend', hamăr jal 'countryman', mattur 'fine fellow', uhmah 'fool', majra 'urban woman, not of native Chuvash origin', ukśa 'money', pělmes 'not to know, not to understand', kil' 'come', kaj 'go', śuk 'no, not to have', hitre 'beautiful', jurat' 'all right', śapla 'yes, that's it'; d) idiomatic expressions: pitě lajăh 'very nice', hullen-hullen 'on the sly, without haste', šutka mar 'none of the joke', kil kunta 'come here', par mana 'give me', kajrămăr 'let's go, come on', Lajăh-i? 'Is it all right?';

- Differentiation of close relatives by age: brat 'elder brother', bratiška 'younger brother'; sestra 'elder sister', sestr'onka 'younger sister'. In the Chuvash language, the nomination of relatives is more fractional than in Russian. In particular, different words are used to nominate elder and younger brothers and sisters as: pičče 'elder brother', šăllăm 'younger brother', appa 'elder sister', jămăk 'younger sister'. The tendency to call younger relatives using deminutive forms is a consequence of this differentiation; 
- The nomination of wheat and rye bread as white and black, as opposed to the official tradition, which is directly due to the Chuvash influence, cf. with Chuvash hura saăkăr 'black bread', šură śăkăr 'white bread';

- The requirement to stop minibuses addressing the drivers the with the word ostav'te 'leave'. This form of requirement by the Russian verb in the imperative mood is dictated by the greater valency of the Chuvash verb Xăvar- 'leave' than its Russian counterpart has;

- Non-distinction between the meanings of the adverbs začem 'for what purpose' and počemu 'for whatever reason', since in the Chuvash language they correspond to the adverbs měnšĕn, ma, mĕn-ma with a universal semantics combining both meanings;

- Substitution of the word stirat' 'laundry, wash' with the word mït' 'wash, clean', cf.: mit' džinsï 'wash, clean jeans' instead of stirat' džinsï 'laundry, wash jeans', which is the result of the Chuvash influence, since the Chuvash verb śu- has meanings of both Russian words.

\subsection{Word Formation Markers}

In the Cheboksary regional dialect of Russian, there occur Chuvash affixes in the composition of Russian words and Russian affixes in the composition of Chuvash ones:

- Širtančik 'little shirtan' < Chuvash šărttan 'homemade sausage' + -čik, a suffix that is a Russian reflection of the Chuvash diminutive affix -čăk (-čěk), while in the Chuvash language there is no expected form šărttančăk;

- Ukśuški diminutive from 'money' < Chuvash ukśa 'money' + Russian -uš + -k(a) + -i;

- Larahat' 'to sit' < Chuvash lar- 'sit' + -ah + Russian -at'; kilehat' 'come' < Chuvash kil- 'come' + -eh + Russian -at'. The model of the formation of Russian verbs based on Chuvash imperatives through an infix formant with the amplifying meaning -ah (-eh) potentially has a total character. Such verbs are inclined according to the rules of the Russian language, cf.: larahaju 'I am sitting', larahaješ 'you are sitting', larahajet 'he is sitting', etc., see also: (Fomin, 2020).

\subsection{Morphological Markers}

In the formation of the Cheboksary regional dialect of Russian morphological markers are of great importance:

- Replacing the forms of possessive pronouns with the corresponding pronouns in genitive case forms preceded by the preposition $u$ : $U$ tebja roditeli doma budut, chto l'? 'Will your parents be at home?' instead of the Russian utterance Tvoi roditeli budut doma? that is in compliance with the literary norm; Mne u Sveti telefon nužen 'I need Sveta's phone number' instead of the Russian normative Mne nužen nomer telefona Sveti. This form is a very widespread phenomenon, which can be explained, firstly, by the very potency of the forms $u+$ personal pronoun in genitive case to signify possessiveness, and secondly, by the influence of Turkic and Finno-Ugric languages of the Ural-Volga region on the Russian language. In Turkic and FinnoUgric languages the semantics of the forms $u$ men'ja and moj are not differentiated;

- Expression of intention, neutral request with the particle -ka: Skažite-ka, moskovskij pojezd vo skol'ko prijedet? 'Tell me, please, when will the train from Moscow arrive?' instead of the Russian normative Skažite, požalujsta, vo skol'ko prid'ot moskovskij pojezd? In the Chuvash language, the particle -ha as in kala-ha expresses a neutral request, functionally corresponding to the Russian požalujsta meaning 'please';

- Formatting questions with the help of particles čto li, čto l', da: Liven' budet, čto l'? 'It is going to rain heavily, isn't it?' instead of the common literary norm Liven' budet? The way Russians use intonation to ask questions is too difficult for the Chuvash. The inhabitants of Cheboksary of Chuvash origin have overcome this difficulty by opting Russian particles čto li, čto l'; da in interrogative utterances;

- Misusing of the dative case with the preposition $k$, ko, e. g. Ko mne segodn'a večerom poznoni 'Call me today in the evening' instead of the normative Poznoni mne segodn'a večerom. In the Chuvash language, the considered forms (man pata 'ko mne', mana 'mne; ko mne') are semantically superimposed on each other, cf.: mana šănkăravla 'call me' = man pata šănkăravla. The analytical form man pata is domineering. Presumably, this marker fits into the same row as the replacement of possessive pronouns with forms of the genitive case with the preposition $u$ (see above);

- Designation of a public transport stop by the nominative case avoiding its agreement with ostanovka 'stop' or even omitting it at times: Dom mod ostav'te 'Leave (me at) Fashion House' instead of the Russian normative Ostanovite na ostanovke "Dom mod" Stop at the bus stop "Fashion house". A similar phenomenon 
occurs in the Chuvash language, when the dative case is replaced by the nominative one, cf.: Ep hula kajap 'I am going to the city' (literally Ja gorod jedu) instead of the normative Ep hulana kajap;

- considering the word čuvaš 'Chuvash' as belonging to the category of limitedly declined ones. Its correct genitive form is čuvašej. However, this ethnonym in the speech of the Cheboksary people tends to the historically conditioned form of the nominalis, cf.: biblionyms of the $19^{\text {th }}$ century - "O muzïke čuvaš" (1852) 'On the Music of Chuvash' instead of the Russian normative o muzïke čuvašej; "Po voprosu o sposobah obrazovanija čuvaš” (1866) 'On the Issue about Educating Chuvash' instead of it there should be po voprosu o sposobah obrazovanija čuvašej.

\subsection{Syntactic Markers}

To date only a few syntactic level markers have been identified in the Cheboksary regional dialect of Russian. It is most likely that this situation is accounted for by the very limited number of such examples registered in recorded speeches of the native inhabitants of Cheboksary:

- Preference for word order arrangement according to the SOV model, which meets the requirements of the Chuvash language, whereas the truely Russian model is that of SVO, see the examples given above: Ko mne segodn'a vecherom poznoni 'Call me tonight'; U tebja roditeli doma budut, chto l'? 'Will your parents be at home?'; Skažite-ka, moskovskij pojezd vo skol'ko prijedet? 'Please tell me what time the Moscow train will arrive?';

- A more frequent use of participial and adverbial expressions in Chuvash, e. g. Reb'onok, vïgulivajuščij sobaku, učits'a $v$ našej škole 'The child walking a dog studies at our school' instead of Reb'onok s sobakoj učits'a $v$ našej škole 'The child with a dog studies at our school, cf. with the corresponding Chuvash utterance Jităpa śüreken ača pirěn škulta věrenet 'The child walking with a dog studies at our school';

- Using the conjunction da in a cause and effect relationship meaning sense: Kak na avtobus uspela? Maršrutka bïstro prijehala da 'How did you catch the bus? - Because the minibus arrived quickly'.

\section{CONCLUSIONS}

Lingvocheboksarika as a general linguistic research into Cheboksary regional dialect of Russian is one of the topical areas of modern Chuvash studies. Currently, it is mainly aimed at studying the Russian language in the Chuvash refraction and is reduced to orthological and sociolinguistic problems.

The Cheboksary regional dialect of the Russian language was formed under the Chuvash influence: most of its manifestations are presumably due to the interference of Chuvash speech traditions with the Russian language system at almost all levels of its functioning. Against the background of the literary language the Cheboksary regional dialect of Russian is distinguished by a number of qualitative and quantitative indicators. The orthoepy of the residents of Cheboksary is distinguished by the literal pronunciation and atypical stress in a number of high-frequency words. A number of Chuvashisms, local urbanonyms, semantic calques of Chuvash words have entered the lexical system of the Cheboksary regional dialect of Russian. Exposed to the Chuvash influence some Russian morphological units are also reduced to their specific use due to the Chuvash participation. Word-formation markers of the Cheboksary regional dialect of Russian are associated with the use of derivational formants of Chuvash origin in Russian word production and Russian suffixes in the composition of Chuvash words. The syntactic level markers are reduced to word order arrangement according to the SOV model characteristic of the Chuvash language whereas a preferable normative model is that of SVO. The high frequency of syntactic structures with participial and adverbial constructions is a characteristic feature of the Cheboksary regional dialect of Russian.

A comprehensive correction of the specific features of the regional dialect allegedly assumed as language mistakes for a long time is no longer possible, since the Russian language in Cheboksary is not able to neutralize the presence of the mighty Chuvash substrate. Rather, we should recognize regional norms of the Russian literary language, its codification and introduction into the system of school and university training. Besides an important purpose of the Cheboksary regional dialect is to preserve the Chuvash material as part of the regional Russian speech.

The study of the Cheboksary regional dialect is one of the first experiments of this kind in Russia, when the object of scientific analysis is the variant of the Russian language that has developed in a foreign language environment. To determine general areal parameters and patterns for analyzing the functioning of the Russian language in the Ural-Volga region, we believe it is necessary to conduct similar studies in other republics as well. 
In Russian regional linguistic studies, a regional dialect is understood as a non-literary entity. Apparently, the perception like this is the result of prioritizing the study of regional dialects functioning in the native Russian regions with varying dialectal manifestations. Anyhow quite a different contactological situation concerning Russian develops in those regions where local languages are used. The mutual influence of languages becomes prominent through mutual interference of contacting languages with each other, Russian being likely to experience the impact of local languages at almost all levels of its functioning.

The speech of the residents of Cheboksary is characterized by their strict adherence to literary norms, while it has outstanding peculiar features which are accounted for by the natives' inadequate mastering and practicing Russian speech culture in use.

\section{ACKNOWLEDGMENTS}

The study was financially supported by the Russian Foundation for Basic Research and the Chuvash Republic as part of scientific project No. 19-412-210001 p_a.

\section{REFERENCE LIST}

Alos-i-Font, E. (2018). On Cheboksary regional dialect (on the base of passengers' requirements to stop minibuses at the stops). Bulletin of I. Y. Yakovlev Chuvash State Pedagogical University, vol. 1.

Alos-i-Font, E. (2012). The attitude of young Russian speaking inhabitants of Cheboksary to the Chuvash language: qualitative research experience. Chuvash people and their neighbors: ethnic cultural dialogue in space-time continuum.

Alos-i-Font, E. (2014). The Chuvash language in the Cheboksary agglomeration (on the research material on Novocheboksarsk and bigger settlements of Cheboksary region). Bulletin of Chuvash State Institute of Culture and Arts, vol. 9.

Bogoroditsky, V. A. (1900). Russian speech inaccuracies of the Chuvash.

Culture and Arts: history and modernity (2013).

Erina, T. N., Fomin, E. V. (2018). Cheboksary talking: on the issues of studying Cheboksary regional dialect of the Russian language. Scientific heritage of $V$. A. Bogoroditsky and modern research vector of Kazan linguistic school, vol. 1.

Erina, T. N., Fomin, E. V. (2019). Orthological aspect of studying the speech of Cheboksary residents. Bulletin of I. Y. Yakovlev Chuvash State Pedagogical University, vol. 3.

Erina, T. N. (2019). Local vocabulary as a feature of the Cheboksary "regiolect" (regional dialect). Ashmarin readings.

Erina, T. N. (2018). Phonetic markers of the Cheboksary regiolect (regional dialect). Language contacts of the peoples of the Volga region and the Urals.

Fomin, E. (2020). Adoption of Russian suffixes by the Chuvash language. Booklet of abstracts. $19^{\text {th }}$ International Morphology Meeting.

Fomin, E. V., Erina, T. N. (2019). Markers of the Cheboksary regional dialect of the Russian language. Ashmarin readings.

Fomin, E. V. (2018). Imitation of the Chuvash accent in Russian speech. Language contacts of the peoples of the Volga region and the Urals.

Livinskaya, I. V. (2015). On the issue of regional variation of the national language. Bulletin of MSOU, vol. 6.

Myshkin, Z. F. (2013). Chuvashisms in the speech of residents of Cheboksary. Culture and art: tradition. 